\title{
Acute abdominal pain caused by superior mesenteric artery syndrome in a healthy young boy
}

Sho Nishiguchi, ${ }^{1}$ Takashi Shirobe ${ }^{2}$

${ }^{1}$ Department of General Internal Medicine, Shonan Kamakura General Hospital, Kamakura, Kanagawa, Japan ${ }^{2}$ Department of Surgery, Narita Tomisato Tokushukai Hospital, Tomisato, Chiba, Japan

\section{Correspondence to}

Dr Sho Nishiguchi, sanazen@ hotmail.co.jp

Accepted 2 December 2016
CrossMark

To cite: Nishiguchi $\mathrm{S}$, Shirobe T. BMJ Case Rep Published online: [please include Day Month Year] doi:10.1136/bcr-2016217512

\section{DESCRIPTION}

A 19-year-old healthy Korean boy presented with severe abdominal pain during the flight from Korea to Japan. Before his flight, the patient had no abdominal pain or surgical history in the past. A knee-chest position could relieve the symptoms. Vital signs were normal except a slight elevation of body temperature. The patient was thin, with a BMI of $16.8 \mathrm{~kg} / \mathrm{m}^{2}$ (figure 1). Abdominal tenderness, distention, and guarding were observed. White cell count was $17.9 \times 10^{3} / \mu \mathrm{L}$ with $81.9 \%$ neutrophil and C reactive protein was $<0.2 \mathrm{mg} / \mathrm{dL}$. Abdominal radiography revealed the dilated stomach (figure 2) and contrast-enhanced CT showed compression at the third part of the duodenum as well as left renal vein (figures 3 and 4), resulted in angulation and reduction in the distance between the aorta and the superior mesenteric artery (SMA), suggesting SMA syndrome. Nasogastric tube drainage yielded about $2000 \mathrm{~mL}$ of fluid, resolving the pain immediately. The diet was begun 1 day after the treatment. The patient was discharged on day 4 .

It was revealed that, just before his flight, the patient had an excessive eating after intentional dieting to avoid the military draft in Korea.

SMA syndrome is a rare disease characterised by compression of the duodenum between the aorta and the SMA. It usually occurs in young and thin females. ${ }^{1}$ A common cause is losing weight by harsh dieting or eating disorders. ${ }^{2}$ For early diagnosis of the patient presenting with abdominal pain, it is necessary to take a recent history of losing weight, regardless their gender and situation.

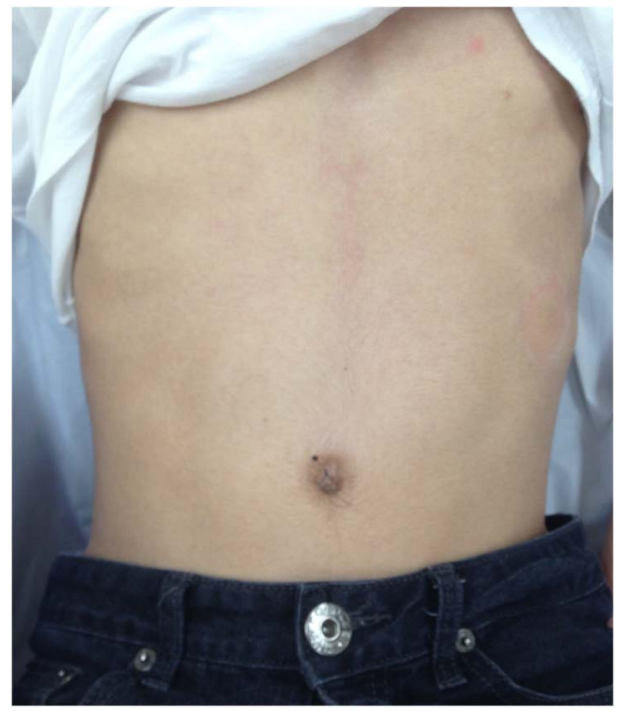

Figure 1 The abdomen of the patient is extremely underweight with distention.

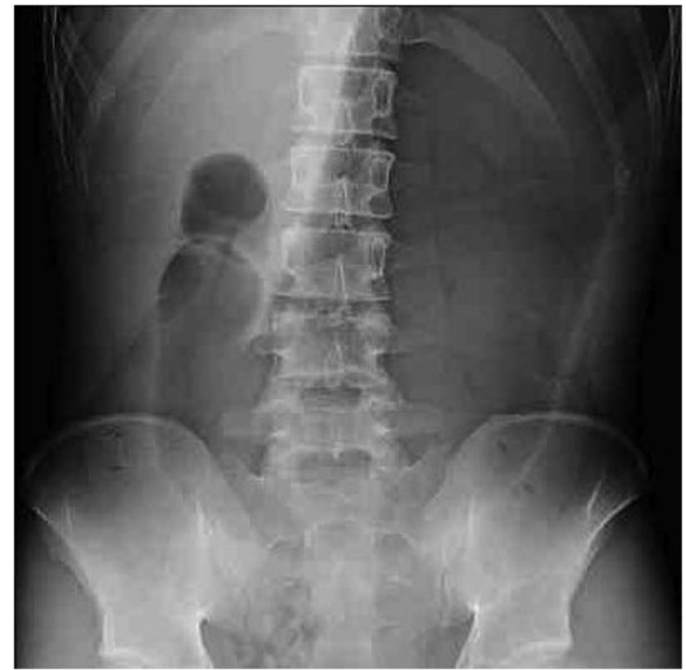

Figure 2 Abdominal X-ray revealed prominent gastric distention.

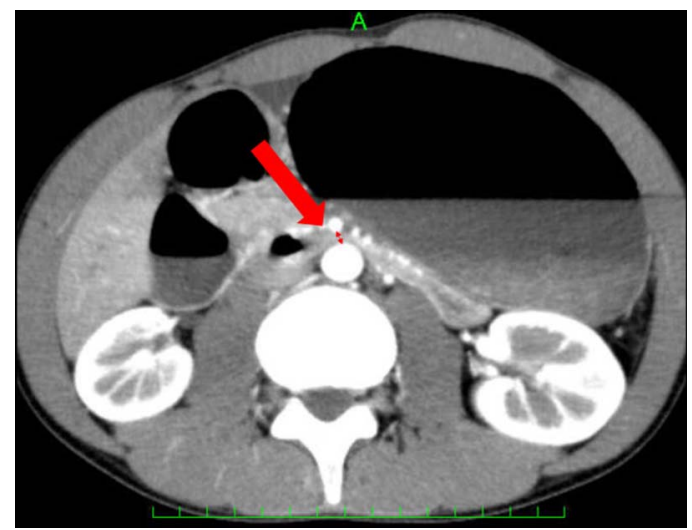

Figure 3 Axial section of abdominal enhanced CT demonstrated the narrowing of the third portion of the duodenum (thick arrow). The distance between the aorta and the superior mesenteric artery (SMA) was indicated (double headed arrow, $4.4 \mathrm{~mm}$ ). The aorta-SMA angle was $9^{\circ}$.

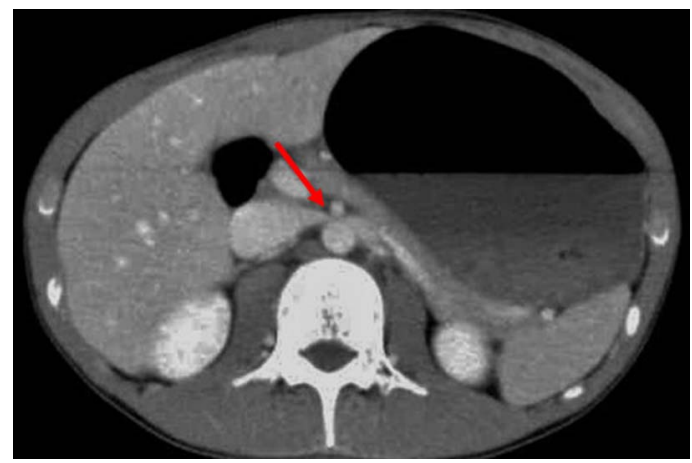

Figure 4 Axial section showed compression of left renal vein (thin arrow) 


\section{Learning points}

- Physicians should check a history of recent excessive eating by the patients with abdominal pain.

- Superior mesenteric artery syndrome may cause acute abdominal pain.

- A thought should be given to the possibility of an intentional dieting by young male.

Acknowledgements The authors thanks Dr. Tomoki Yokochi for his editorial support.
Contributors SN provided the manuscript. TS edited the manuscript.

Competing interests None declared.

Patient consent Obtained.

Provenance and peer review Not commissioned; externally peer reviewed.

\section{REFERENCES}

1 Unal B, Aktas A, Kemal G, et al. Superior mesenteric artery syndrome: CT and ultrasonography findings. Diagn Interv Radiol 2005;11:90-5.

2 Ricca RL, Kasten J, Javid PJ. Superior mesenteric artery syndrome after minimally invasive correction of pectus excavatum: impact of post-operative weight loss.

J Pediatr Surg 2012;47:2137-9.

Copyright 2016 BMJ Publishing Group. All rights reserved. For permission to reuse any of this content visit http://group.bmj.com/group/rights-licensing/permissions.

BMJ Case Report Fellows may re-use this article for personal use and teaching without any further permission.

Become a Fellow of BMJ Case Reports today and you can:

- Submit as many cases as you like

- Enjoy fast sympathetic peer review and rapid publication of accepted articles

- Access all the published articles

- Re-use any of the published material for personal use and teaching without further permission

For information on Institutional Fellowships contact consortiasales@bmjgroup.com

Visit casereports.bmj.com for more articles like this and to become a Fellow 